УКД 651:51

(C) 2012

Григорів Я. Я., аспірант *

Івано-Франківський інститут АПВ НААН України

\title{
ЕКОНОМІЧНА ЕФЕКТИВНІСТЬ ВИРОЩУВАННЯ РИЖІЮ ЯРОГО В УМОВАХ ПРИКАРПАТТЯ
}

\section{Рецензент - кандидат сільськогосподарських наук Н. М. Лис}

\begin{abstract}
Висвітлені результати досліджень, проведених упродовж 2009-2011 рр. у стаціонарному польовому досліді на дерново-підзолистих грунтах, із вивчення ефективності застосування різних технологій вирощування на продуктивність рижію ярого й, відповідно, економічну ефективність вирощування даної культури. Виявлено залежність елементів продуктивності та урожайності від застосування мінеральних добрив. Встановлено, щзо внесення мінеральних добрив мало значний вплив на продуктивність насіння рижію ярого $і$ на показник собівартості та рентабельності насіння рижію ярого відповідно.
\end{abstract}

Ключові слова: собівартість, рентабельність, урожайність, технології, рижій.

Постановка проблеми. Світовий досвід переконує: шлях до подолання кризової ситуації полягає насамперед у виробництві конкурентоздатної продукції як для внутрішнього, так і для зовнішнього ринків, що відповідає купівельній спроможності споживача й водночас вигідна виробнику. Досягти цього можна на основі комплексного підходу до виробництва і практики реалізації продукції рослинництва й широкого освоєння останніх науково-технічних досліджень. Постає необхідність дедалі цілеспрямованіше впроваджувати у виробництво апробовані світовою й вітчизняною практикою культури 3 високим урожайним потенціалом, які 3 тих чи інших причин не набули ще належного поширення. До таких культур у нашій країні належить рижій [1].

Економічні методи оцінки технологій вирощування сільськогосподарських культур у певній мірі $€$ недостатніми, поскільки мають значні коливання, що зумовлені насамперед ціновою політикою. Енергетичний аналіз дає можливість у значній мірі уникнути цих коливань й отримати більш об'єктивну характеристику технологічних процесів вирощування культурних рослин. Отже, енергетична та економічна оцінки технологічних процесів вирощування сільськогоспо- дарських культур взаємодоповнюють одна одну і мають актуальне значення для сучасного сільськогосподарського виробництва України [2].

Аналіз досліджень, у яких започатковано розв'язання проблеми. На сучасному етапі розвитку агропромислового виробництва створення додаткової рослинницької продукції потребує значних затрат матеріальних та енергетичних ресурсів. Однак енергетичні ресурси в нашій країні обмежені, а виробництво енергії поступово дорожчас. Тому одержання максимальної кількості рослинницької продукції за мінімальних затрат енергії $€$ пріоритетним i необхідним завданням сучасної аграрної науки [3, 4].

Визначення економічної та біоенергетичної ефективності при розробці нових та удосконаленні існуючих технологій вирощування рижію ярого, які базувалися на різних строках посіву й внесенні різних норм мінеральних добрив, було важливим і необхідним завданням наших досліджень.

Мета - розробити найефективнішу ресурсозберігаючу технологію вирощування насіння рижію ярого для господарств різних форм власності 3 рентабельною продуктивністю насіння, придатного на харчові, технічні та кормові цілі.

Матеріал і методика досліджень. Дослідження проводили протягом 2009-2011 pр. на дослідному полі технологічної сівозміни ІваноФранківського інституту АПВ.

Грунти дослідної ділянки - дернові глибоко опідзолено глеюваті, 3 наступною агрохімічною характеристикою орного шару (0-25 см): $\mathrm{pH}$ сольове $-5,10-5,65$; вміст рухомого $\mathrm{P}_{2} \mathrm{O}$ та обмінного $\mathrm{K}_{2} \mathrm{O}$ (за Кірсановим), - відповідно, 7,6-11,3 мг та $8,3-13,8$ мг на 100 г грунту; азот, що легко гідролізується, (за Корнфільдом) - 6,2-7,7 мг на 100 г грунту. Дослід закладався у чотириразовому повторенні, площа облікової ділянки $-20 \mathrm{~m}^{2}$.

Попередник - пшениця озима. Сівбу проводили згідно зі схемою досліду. Для сівби використовували сорт Гірський селекції інституту АПВ.

* Керівник-доктор сільськогосподарських наук В. Ф. Камінський 
Зважаючи на нечутливість рижію до внесення калійних добрив [3], вивчали вплив лише азотних i фосфорних добрив. У досліді мінеральні добрива у вигляді аміачної селітри та гранульованого суперфосфату вносили під основний обробіток грунту за схемою:

Контроль - без добрив;

Фон - $\left(\mathrm{N}_{0} \mathrm{P}_{45} \mathrm{~K}_{45}\right)$;

Фон - $\left(\mathrm{N}_{30} \mathrm{P}_{45} \mathrm{~K}_{45}\right)$;

ФоH $-\left(\mathrm{N}_{30} \mathrm{P}_{45} \mathrm{~K}_{45}\right)+\mathrm{N}_{60}$;

Фон $-\left(\mathrm{N}_{30} \mathrm{P}_{45} \mathrm{~K}_{45}\right)+\mathrm{N}_{30}$.

Закладання дослідів і проведення досліджень виконували у відповідності з загальноприйнятими методиками польових дослідів у землеробстві й рослинництві.

На всіх варіантах дослідів проводилися фенологічні спостереження за методикою Держкомісії із сортовипробування сільськогосподарських культур. Облік урожаю проводили методом суцільної облікової ділянки з перерахунком на гектар.

Результати досліджень. У дослідженнях вивчався вплив технології вирощування на урожайність насіння рижію ярого.

У процесі вирощування рижію головним завданням сільськогосподарського виробництва на сучасному етапі $\epsilon$ збільшення прибутковості виробництва зі збільшенням сільськогосподарської продукції з мінімальними затратами енергії та ресурсів [3].

Встановлено, що досліджувані строки сівби та норми мінеральних добрив суттєво впливали на показники економічної ефективності вирощування рижію ярого (див. табл.). Визначаючи виробничі затрати на виконання робіт, нами включалися суми на оплату праці, вартість обробітку грунту, гербіцидів, насіння, відрахування на амортизацію, поточний ремонт і техогляд, вартість палива й мастильних матеріалів, мінеральних добрив, а також витрати на зберігання насіння.

Розрахунки економічної ефективності вирощування рижію ярого наведені в цінах 2010 року. Найвищі виробничі витрати були за третього строку сівби (через 10 днів після першої сівби) за різних фонів удобрення.

Кращі показники економічної ефективності, зокрема вартість урожаю (38029 грн), відмічено за першого строку сівби на варіанті з внесенням мінеральних добрив у нормі $\mathrm{N}_{30} \mathrm{P}_{45} \mathrm{~K}_{45}+\mathrm{N}_{60}$.

Прибуток і собівартість при цьому складали, відповідно, 33248 грн/га та 277,97 грн/ц.

На ділянках, де вносили фосфорні й калійні добрива $\left(\mathrm{P}_{45} \mathrm{~K}_{45}\right)$ i застосовували гербіцид, показники економічної ефективності, а саме собівартість, зменшувалися порівняно з іншими варіантами.

Так, основні показники економічної ефективності мали значення: прибуток - 27211,1 грн/га, рівень рентабельності - $118 \%$, собівартість - 133,8 грн/ц за першого строку сівби, а за другого строку сівби: прибуток - 22789,1 грн/га, ріветь рентабельності $122 \%$, собівартість - 157,92 грн/ц, й, відповідно, за третього строку сівби: прибуток - 24557,1 грн/га, рівень рентабельності - $120 \%$, собівартість 147,30 грн/ц.

\section{Економічна ефективність технологій вирощування рижію ярого} (у середньому за 2009-2010 рр.)

\begin{tabular}{|c|c|c|c|c|c|c|c|}
\hline $\begin{array}{c}\text { Строки } \\
\text { сівби }\end{array}$ & $\begin{array}{c}\text { Мінеральне } \\
\text { живлення }\end{array}$ & $\begin{array}{c}\text { Урожай- } \\
\text { ність, } \\
\text { ц/га }\end{array}$ & $\begin{array}{c}\text { Вартість } \\
\text { урожаю, } \\
\text { грн/га }\end{array}$ & $\begin{array}{c}\text { Виробничі } \\
\text { затрати, } \\
\text { грн/га }\end{array}$ & $\begin{array}{c}\text { Чистий } \\
\text { прибуток, } \\
\text { грн/га }\end{array}$ & $\begin{array}{c}\text { Собівар- } \\
\text { тість } \\
1 \text { ц, грн }\end{array}$ & $\begin{array}{c}\text { Рівень } \\
\text { рен- } \\
\text { табельнос- } \\
\text { ті, \% }\end{array}$ \\
\hline За темпе- & без добрив (контроль) & 8,1 & 17909 & 1966,9 & 15942,1 & 242,83 & 138 \\
ратури гру- & $\mathrm{P}_{45} \mathrm{~K}_{45}$ & 13,1 & 28964 & 1752,9 & 27211,1 & 133,8 & 118 \\
нту 1-2 ${ }^{0} \mathrm{C}$ & $\mathrm{N}_{30} \mathrm{P}_{45} \mathrm{~K}_{45}$ & 14,9 & 32944 & 4286,9 & 28657,1 & 287,71 & 148 \\
& $\mathrm{~N}_{30} \mathrm{P}_{45} \mathrm{~K}_{45}+\mathrm{N}_{60}$ & 17,2 & 38029 & 4781 & 33248 & 277,97 & 146 \\
\hline Через 5 & $\mathrm{N}_{30} \mathrm{P}_{45} \mathrm{~K}_{45}+\mathrm{N}_{30}$ & 15,9 & 35154 & 4475,4 & 30678,6 & 281,47 & 147 \\
днів після & безрив добонтроль) $_{\text {першого }}$ & 6,2 & 13708 & 1966,9 & 11741,1 & 317,24 & 156 \\
птроку & $\mathrm{P}_{45} \mathrm{~K}_{45}$ & 11,1 & 24542 & 1752,9 & 22789,1 & 157,92 & 122 \\
сівби & $\mathrm{N}_{30} \mathrm{P}_{45} \mathrm{~K}_{45}$ & 12,3 & 27195 & 4286,9 & 22908,1 & 348,53 & 165 \\
\hline Через 10 & $\mathrm{N}_{30} \mathrm{P}_{45} \mathrm{~K}_{45}+\mathrm{N}_{60}$ & 13,8 & 30511 & 4781 & 25730 & 346,45 & 165 \\
днів після & $\mathrm{N}_{30} \mathrm{P}_{45} \mathrm{~K}_{45}+\mathrm{N}_{30}$ & 12,6 & 27858 & 4475,4 & 23382,6 & 355,19 & 168 \\
першого & $\mathrm{P}_{45} \mathrm{~K}_{45}$ & 11,9 & 26310 & 1752,9 & 24557,1 & 147,30 & 146 \\
строку & $\mathrm{N}_{30} \mathrm{P}_{45} \mathrm{~K}_{45}$ & 13,3 & 29406 & 4286,9 & 25119,1 & 322,32 & 158 \\
сівби & $\mathrm{N}_{30} \mathrm{P}_{45} \mathrm{~K}_{45}+\mathrm{N}_{60}$ & 14,5 & 32059 & 4781 & 27278 & 329,72 & 159 \\
\hline
\end{tabular}


Найвища собівартість одного центнера насіння зафіксована за другого строку сівби, що пояснюється суттєвим зниженням урожайності на цих варіантах досліду. Так, на варіанті без застосування добрив показник собівартості знаходився у межах 317,24 грн за 1 ц, тоді як за першого строку сівби даний показник складав 242,83 грн за 1 центнер.

Найменша собівартість одного центнера насіння отримана на варіантах, де вносили фосфорні й калійні добрива у нормі $\mathrm{P}_{45} \mathrm{~K}_{45}$, що становить 133,8 грн/ц - за першого строку сівби, 157,92 грн/ц - за другого, та 147,30 грн/ц - за третього.

Різна продуктивність посівів рижію ярого обумовила отримання різного рівня рентабельності. Розрахунки свідчать, що найвищий рівень рентабельності у вирощуванні рижію ярого на насіння отриманий за другого строку сівби (через 5 днів після першого) і становив 168,0 \% на варіанті, де вносили мінеральні добрива у нормі $\mathrm{N}_{30} \mathrm{P}_{45} \mathrm{~K}_{45}+\mathrm{N}_{30}$. Найнижчий рівень рентабельності спостерігали за другого строку сівби (через 5 днів після першого строку сівби) на варіанті досліду із внесенням мінеральних добрив у нормі $\mathrm{P}_{45} \mathrm{~K}_{45}$, який становив $118 \%$.

Необхідно відзначити, що застосування мінеральних добрив у нормах $\mathrm{P}_{45} \mathrm{~K}_{45}, \mathrm{~N}_{30} \mathrm{P}_{45} \mathrm{~K}_{45}$,

\section{БІБЛІОГРАФІЯ}

1. Аграрні вісті [Текст] : Всеукраїнський журнал: «Кондор», 2007-2008. - № 6. - С. 3-5.

2. Бородин И. В. Рыжик / Бородин И. В. - Новосибирск: Новосиб. обл. гос. изд-во, 1952 . -88 с.

3. Рослинництво 3 основами землеробства / М. А. Білоножко, I. С. Руденко, В. І. Мойсеєнко
$\mathrm{N}_{30} \mathrm{P}_{45} \mathrm{~K}_{45}+\mathrm{N}_{60}, \quad \mathrm{~N}_{30} \mathrm{P}_{45} \mathrm{~K}_{45}+\mathrm{N}_{30}$ сприяло значному покращанню показників економічної ефективності порівняно $з$ ділянками без мінеральних добрив. Собівартість одиниці врожаю знижувалася (29,52 -144,97 грн/ц), а чистий прибуток і рівень рентабельності підвищувалися, відповідно, на $17305,9-13988,9$ грн/га та 41,4-134,6 \%. Висока економічна ефективність проведення підживлень на посівах рижію ярого пояснюється збільшенням рівня урожайності насіння за відносно низьких витрат ресурсів.

Слід вказати на суттєві відміності між показниками економічної ефективності застосування мінеральних добрив за різних строків сівби. Так, за першого строку сівби за рахунок формування вищої врожайності насіння собівартість одиниці врожаю зменшувалася на 214,15 грн/ц, а прибуток та рівень рентабельності збільшувалися на 792,4 грн/га та 64,0 \% порівняно із наступними строками сівби.

Висновок. Кращі показники економічної ефективності (рівень рентабельності та собівартість) одержано за першого строку сівби на варіантах досліду із застосуванням фосфорних i калійних мінеральних добрив. Найвищий прибуток отримано на ділянках із внесенням мінеральних добрив у нормі $\mathrm{N}_{30} \mathrm{P}_{45} \mathrm{~K}_{45}+\mathrm{N}_{60}$ за другого строку сівби.

[та ін.]; за ред. М. А. Білоножка, I. С. Руденка. К.: Урожай, 1986. - 224 с.

4. Соловей Д. Ю. Досвід застосування енергетичного аналізу для оцінки технологічних процесів і технологій у рослинництві / Соловей Д. Ю. // Економіка АПК, 2004. - № 4. - С. 91-94. 